\title{
KEDUDUKAN HUKUM BAGI ANAK YANG LAHIR KARENA KAWIN HAMIL (MARRIED BY ACCIDENT) DI TINJAU DARI HUKUM ISLAM DAN HUKUM PERDATA
}

\author{
Enik Isnaini $^{*}$ \\ "Dosen Fakultas Hukum Universitas Islam Lamongan
}

\begin{abstract}
ABSTRAK
Sering dijumpai ditengah tengah masyarakat ada seorang wanita yang melahirkan seorang anak hasil dari hubungan diluar nikah dan masyarakat menyebutnya dengan sebutan anak haram, anak zina, anak jadah dan anak terlaknat. Yang perlu diluruskan adalah sebutan tersebut adalah keliru dan salah sasaran. Karena seakan akan dengan sebutan tersebut si anaklah yang salah dan berdosa. Sebenarnya jika kita melihatnya dengan lurus dan proporsional, sesungguhnya kelahiran anak dari hasil zina tidak salah dan tidak berdosa. Islam mengakui semua anak yang lahir ke alam ini suci dan bersih tanpa memandang kedua orangtuanya.

Adanya perbedaan pendapat dikalangan para ulama yang membingungkan para pelaku dalam hal menyelesaikan permasalahan yang timbul akibat hamil diluar nikah dan beberapa akibat hukum dari hamil diluar nikah serta status anak yang akan dilahirkannya nanti, sementara Kitap Undang-undang Hukum Perdata (BW) tidak secara tegas mengatur tentang wanita yang hamil sebelum akad nikah dilangsungkan dan status hukum yang disandang anak yang dilahirkannya. Tidak dapat dipungkiri bahwa pernikahan yang di awali dengan perzinahan pada akhirnya akan membawa banyak permasalahan yang sangat kompleks yang saat ini sering diabaikan. Oleh karena itu terdapat masalah dalam status hukum bila akad nikah/perkawinan dilangsungkan pada saat mempelai wanita dalam keadaan hamil baik dengan laki-laki yang menghamilinya maupun dengan laki-laki lain.
\end{abstract}

Kata Kunci : Kedudukan hukum, awin hamil, hukum Islam dan hukum Perdata.

\section{PENDAHULUAN}

\section{1 . 1 Latar Belakang}

Islam adalah agama yang benar di sisi Allah. Ia memiliki hukum yang bersumber dari al-Qur'an dan Hadits. Seperti halnya hukum anak. Dalam Islam, yang disebut anak sah adalah anak yang dilahirkan di dalam pernikahan yang sah sesuai dengan ketentuan ajaran Islam. Oleh karena itu, ia memiliki kedudukan baik, terhormat, dan berhak mendapatkan hak-haknya, seperti nasab, perwalian, serta hak waris.

Dalam kenyataan sekarang, banyak anak yang lahir di luar perkawinan sebagai akibat dari perilaku seks bebas. Ironinya, perilaku seks bebas banyak dilakukan di kalangan remaja. Kebanyakan dari pelaku seks bebas hanya memikirkan kenikmatan sesaat, tanpa sadar akibat yang akan 
ditimbulkan dari perbuatannya. Salah satu akibat dari seks bebas adalah lahirnya anak di luar kawin.

Sifat suci dan bersih menurut konsep islam itu dimiliki oleh setiap anak yang lahir. Karena masalah dosa dalam islam tidak dikenal adanya dosa turunan. Dosa harus ditanggung oleh setiap manusia yang melakukannya. Hal ini ditegaskan oleh Allah SWT yang artinya bahwasanya seorang yang berdosa tidak akan memikul dosa orang lain. (QS. Al Najm:38).

Dimana menurut aturan tersebut tidak semua golongan penduduk tunduk pada aturan-aturan BW. Sehingga sampai dengan saat ini tidak semua masyarakat Indonesia tunduk pada aturan ini, hanya golongan yang diberlakukan BW saja yang harus patuh pada aturan ini, yaitu golongan tionghoa dan golongan pribumi yang melakukan penundukan diri pada aturan-aturan BW. ${ }^{1}$

Dalam ketentuan Kitab UndangUndang Hukum Perdata dan Hukum Islam menyatakan bahwa anak di luar nikah tidak dapat dihubungkan dengan ayahnya, melainkan hanya kepada ibunya dan keluarga ibunya. Namun demikina, ketentuan dalam KUHP dapat berubah apabila anak tersebut mendapat pengakuan sekaligus pengesahan. Dan akibat dari pengakuan dan pengesahan tersebut akan timbul hak dan kewajiban timbal balik antara anak dengan orang tuanya.

\section{1 .2 Perumusan Masalah}

Berdasarkan uraian latar belakang masalah diatas maka penulis mengetengakan dua permasalahan yaitu:

1 Subekti, Pokok-pokok Hukum Perdata, PT. Intermasa, h. 10.
- Bagaimana kedudukan hukum anak yang lahir karena Perkawinan Dalam Keadaan Hamil (Married By Accident) menurut Hukum Islam dan KUH Perdata?

- Bagaimana Akibat Hukum bagi anak yang lahir karena Perkawinan Dalam Keadaan Hamil (Married By Accident) menurut hukum islam dan hukum perdata?

\section{1 . 3 Tujuan Penelitian}

Tujuan yang diharapkan dari penelitian ini adalah sebagai berikut:

- Untuk mengetahui kedudukan hukum bagi anak yang lahir di luar ikatan perkawinan yang sah dengan orang tuanya menurut Hukum Islam dan Hukum Perdata.

- Untuk mengetahui Akibat Hukum bagi anak yang lahir karena Perkawinan Dalam Keadaan Hamil (Married By Accident) menurut hukum islam dan hukum perdata.

\section{4 Manfaat Penelitian}

a. Manfaat Teoritis

Adapun hasil penelitian ini sangat diharapkan dapat memberikan manfaat teoritis yang akan memperkaya literatur ilmu hukum guna membangun argumentasi ilmiah sebagai acuan untuk menemukan kekurangan-kekurangan dalam pendekatan penelitian normatif terhadap hukum keluarga terutama yang terkait dengan masalah kedudukan hukum anak luar kawin khususnya anak yang lahir karena Perkawinan Dalam Keadaan Hamil (Married By Accident), Serta untuk mengisi kekosongan hukum keluarga dalam masalah kedudukan hukum anak luar kawin, yang sampai dengan saat ini belum diatur secara rinci dalam peraturan perundang-undangan.

b. Manfaat Praktis 
Manfaat praktis penelitian ini bagi masyarakat diharapkan dapat memberikan argumentasi hukum untuk perlindungan anak luar kawin serta dapat memperjelas hubungan hukum antara orang tua anak luar kawin dengan anak luar kawin. Terutama dalam pemberian status hukum bagi anak yang lahir karena Perkawinan Dalam Keadaan Hamil (Married By Accident) terhadap ayah dan ibunya. Manfaat praktis penelitian ini bagi para praktisi hukum terutama hakim dalam hal terjadinya sengketa tentang kedudukan anak yang lahir karena Perkawinan Dalam Keadaan Hamil (Married By Accident) diharapkan dapat memberikan bahan masukan dan pertimbangan hakim dalam memeriksa perkara yang berkaitan dengan kedudukan hukum anak yang lahir karena Perkawinan Dalam Keadaan Hamil (Married By Accident), baik yang bersifat volunteer maupun yang bersifat contentious.

\section{5 Metode Penelitan}

\section{a. Type Penelitian}

Type penelitian hukum yang dilakukan adalah yuridis normative (hukum normatif). Metode penelitian hukum normatif adalah suatu prosedur penelitian ilmiah untuk menemukan kebenaran berdasarkan logika keilmuan hukum dari sisi normatifnya. ${ }^{2}$

Oleh karena itu penelitian hukum ini difokuskan untuk mengkaji penelitian hukum tentang kaidah-kaidah atau norma-norma dalam hukum positif, yakni norma hukum yang terkait dengan Kedudukan Hukum Anak yang lahir karena Perkawinan dalam keadaan hamil (Married By Accident) di tinjau dari Hukum Islam dan Hukum Perdata serta Akibat hukumnya.

\section{b. Pendekatan Masalah}

Oleh karena type penelitian yang digunakan adalah tipe penelitian yuridis normatif, maka pendekatan yang digunakan adalah pendekatan perundang-undangan (statute approach).

Pendekatan tersebut melakukan pengkajian peraturan perundangundangan yang berhubungan dengan pokok permasalahan. Selain itu juga digunakan pendekatan konsep (Conceptual approach). Pendekatan konsep ini digunakan dalam rangka untuk melihat konsep-konsep mengenai Kedudukan Hukum Anak yang lahir karena Perkawinan dalam keadaan hamil (Married By Accident) di tinjau dari Hukum Islam dan Hukum Perdata serta Akibat hukumnya.

\section{c. Bahan Hukum}

Bahan hukum yang dipergunakan dalam penelitian ini menggunakan bahan hukum primer dan sekunder.

Bahan hukum primer adalah bahan hukum yang terdiri dari aturanaturan hukum yang diurut berdasarkan hierarki.

Bahan sekunder adalah bahan hukum yang diperoleh dan dikumpulkan dari literatur-literatur, pendapat para sarjana, artikel dalam surat kabar maupun majalah serta laporan hasil penelitian dan karya ilmiah yang telah disusun dalam bentuk makalah atau skripsi yang membahas masalah kedudukan hukum anak luar kawin atau yang sejenis.

2 Johny Ibrahim, Teori \& Metode Penelitiah Hukum Normatif, Banyumedia Publiching Malang 2006, h. 57.

\section{d. Prosedur Pengumpulan Bahan- bahan}

Baik bahan primer maupun sekunder dikumpulkan berdasarkan topic permasalahan yang telah dirumuskan dan diklasifikasi menurut sumber dan hirarkinya untuk dikaju secara komprehensif. 


\section{e. Pengelolahan dan Analisis Bahan Hukum}

Adapun bahan yang diperoleh dalam penelitian studi kepustakaan, aturan perundang-undangan, yang penulis uraiakan dan dihubungkan sedemikian rupa, sehingga disajikan dalam penulisan yang lebih sistenatis guna menjawab perumusan masalah yang dirumuskan. Cara perolehan data dilakukan secara deduktif yakni menarik kesimpulah dari suatu permasalahan kongkrit yang dihadapi.

Keseluruhan data yang diperoleh baik primer maupun sekunder dianalisis secara kualitatif dan diberikan penggambaran mengenai hubungan hukum dan Akibat Hukum bagi Anak yang lahir di luar ikatan perkawinan menurut hukum islam dan hukum perdata dalam Perolehan warisan dan Perwaliannya.

\section{f. Sistematika Penulisan}

Bab I Pendahuluan yang berisi tentang latar belakang permasalahan, perumusan masalah, tujuan dan manfaat penelitian, metode penelitian dan Sistem penulisan.

Bab II membahas tentang Kedudukan hukum bagi anak yang lahir karena Perkawinan Dalam Keadaan Hamil (Married By Accident) menurut Hukum Islam dan KUH Perdata. Dalam bab ini akan diuraikan dalam sub. Bab yang meliputi : Pengertian Perkawinan, Pengertian Anak, dan Kedudukan Hukum Bagi Anak Yang Lahir Karena Perkawinan dalam keadaan hamil (Married By Accident) Di Tinjau Dari Hukum Islam dan Hukum Perdata.

Bab III membahas tentang Akibat hukum bagi anak yang lahir karena Perkawinan dalam keadaan hamil (Married By Accident) menurut hukum islam dan hukum perdata. Dalam bab ini akan diuraikan sub. Bab yang meliputi :
Pengertian dan dasar hukum Kewarisan menurut Hukum Islam dan KUHPerdata (BW), Sebab-sebab mewarisi dan penghalang mendapatkan bagaian harta warisan, Pengertian Wali Nikah, dan Akibat Hukum Bagi Anak Yang Lahir Karena Perkawinan Dalam Keadaan Hamil (Married By Accident) Menurut Hukum Islam Dan Hukum Perdata

Bab IV Penutup yang berisi tentang Kesimpulan dari seluruh pokok pembahasan dan saran disampaikan sebagai masukan guna perbaikan penulisan berikutnya.

\section{HASIL DAN PEMBAHASAN}

Perkawinan (nikah) adalah ikatan lahir dan batin antara seorang laki-laki dan perempuan untuk memenuhi tujuan hidup berumah tangga sebagai suamiistri yang dengan memenuhi syarat dan rukun yang telah ditentukan oleh syariat islam. ${ }^{4}$ Perkawinan dalam islam bukan hanya bertujuan untuk kenikmatan seksual semata, melainkan untuk membentuk terciptanyan sebuah keluarga, terbinanya sebuah masyarakat, bangsa dan Negara yang kuat.

Hukum nikah menurut islam ada empat macam, yaitu :

a. Wajib, bagi orang yang mengharapkan keturunan, takut akan berbuat zina jika tidak menikah, baik dia ingin menikah atau tidak, meskipun pernikahahnnya akan memutuskan ibadah yang tidak wajib. Dan bagi wanita yang lemah dalam memelihara dirinya dan tidak ada benteng lain kecuali nikah.

b. Makruh, bagi orang yang tidak ingin menikah dan tidak mengharapkan keturunan, serta pernikahannya dapat memtuskan ibadah yang tidak wajib.

c. Mubah, bagi orang yang tidak khawatir melakukan zina, tidak mengharapkan keturunan, dan tidak 
memutuskan ibadah yang tidak wajib.

d. Haram, bagi orang yang mebahayakan wanita, karena tidak mampu melakukan senggama, tidak mampu member nafkah atau memiliki pekerjaan haram, meskipun ia ingin menikah dan tidak khawatir berbuat zina. Pembagian hokum ini juga berlaku bagi seorang wanita.

Rukun nikah ada lima, yaitu Calon Suami, Calon Istri, Wali nikah, dua orang saksi dan kalinat pernikahan (ijab dan qabul).

Sedangkan hikmah dan tujuan pernikahan menurut islam adalah sebagai beikut :

- Menciptakan ketenangan dan ketentreraman

- Untuk memperoleh keturunan

- Untuk menyalurkan kebutuhan biologis (seks) secara sah dan halal antara laki-laki dan perempuan

- Memperkokoh hubungan keluarga, antar mertua dan masyarakat sekitar.

Pendapat lain menyatakan bahwa Perkawinan adalah suatu cara yang dipilih Allah sebagai jalan bagi manusia untuk beranak, berkembang biak dan melestarikan hidupnya, setelah masingmasing pasangan siap melakukan peranannya yang positif dalam mewujudkan tujuan perkawinan. ${ }^{3}$

Sehingga hubungan antara lakilaki dan perempuan diatur secara terhormat dan berdasarkan saling meridhai, dengan upacara ijab dan qabul sebagai lambang dari adanya rasa ridhameridhai, dan dengan dihadiri para saksi yang menyaksikan kalau pasangan lakilaki dan perempuan itu telah saling terikat.

Perkawinan wanita hamil adalah seorang wanita yang hamil sebelum melangsungkan akad nikah, kemudian dinikahi oleh pria yang
menghamilinya.Oleh karena itu, masalah perkawinan wanita hamil harus dibutuhkan penelitian dan perhatian yang bijaksana terutama Pegawai Pembantu Pencatat Nikah (P3N).Tentang hamil diluar nikah sendiri sudah kita ketahui sebagai perbuatan zina baik oleh pria yang menghamilinya maupun wanita yang hamil.Dan itu merupakan dosa besar.

Para ulama berbeda pendapat dalam masalah ini, ada yang secara ketat tidak memperbolehkan, ada pula yang menekankan pada penyelesaian masalah tanpa mengurangi kehati-hatian mereka. Sejalan dengan sikap para ulama itu, ketentuan hukum Islam menjaga batasbatas pergaulan masyarakat yang sopan dan memberikan ketenangan dan rasa aman. Patuh terhadap ketentuan hukum Islam, insya Allah akan mewujudkan kemaslahatan dalam masyarakat.

Asas pembolehan pernikahan wanita hamil ini dimaksudkan untuk memberi perlindungan kepastian hukum kepada anak yang ada dalam kandungan, dan logikanya untuk mengakhiri status anak zina.

Kompilasi Hukum Islam di Indonesia yang dinyatakan berlakunya dengan Instruksi Presiden Nomor 1 tahun 1991 sebagai pedoman bagi hakim di lembaga peradilan agama juga membicarakan perkawinan perempuan hamil karena zina dan dinyatakan boleh.

Pasal yang menyatakan kebolehan mengawini perempuan hamil itu, secara langsung juga tidak dijelaskan status anak yang lahir dari perempuan yang dulunya sudah hamil. Namun Kompilasi Hukum Islam di Indonesia dalam pasal lain menjelaskan status anak. Dalam pasal itu dinyatakan bahwa anak sah adalah anak yang lahir dalam atau akibat dari suatu perkawinan yang sah. 
3 Mohammad Thalib. (Trans) Sayyid Sabiq, Fikih Sunnah. (Bandung : PT. Alma'arif, 1980. Jilid 6, Cet 15, h. 7.

Dalam hukum yang berlaku di Indonesia, masalah kawin hamil dijumpai dalam Kompilasi Hukum Islam pasal 53 menyebutkan:

1) "Seorang wanita hamil di luar nikah, dapat dikawinkan dengan pria yang menghamilinya.

2) Perkawinan dengan wanita hamil yang disebut pada ayat (1) dapat dilangsungkan tanpa menunggu lebih dahulu kelahiran anaknya.

3) Dengan dilangsungkannya perkawinan pada saat wanita hamil, tidak diperlukan perkawinan ulang setelah anak yang dikandung lahir."

Kompilasi Hukum Islam nampaknya hanya mengatur perkawinan wanita hamil di luar nikah. Tidak mengatur perkawinan wanita hamil yang legal dari suami yang nikah secara sah, yang kemudian cerai atau meninggal sesuai dengan An-Nuur: 3. Abdur Rahman Ba'alawy mengatakan: Boleh menikahi wanita yang hamil dari zina baik dengan laki-laki yang menghamilinya atau bukan dan menggaulinya di waktu hamil disertai hukum makruh.

Ketentuan pada pasal 53 di atas sejalan dengan ketentuan yang terdapat dalam al-Qur'an surat an-Nur ayat 3 yang dikutip di atas, bahwa pezina perempuan tidak layak dikawinkan kecuali dengan pezina laki-laki, dan hal itu diharamkan terhadap oang-orang yang beriman.

Perkawinan dalam kasus ini dapat dilangsungkan tanpa menunggu kelahiran bayi, dan anak yang dikandung dianggap mempunyai hubungan darah dan hukum yang sah dengan pria yang mengawini wanita tersebut. Di sinilah letak kompromistis antara hukum Islam dan hukum adat dengan menimbang pada kemaslahatan, aspek sosiologis dan psikologis.

Dalam fenomena nikah hamil, akan muncul nilai yang kontroversial. Pengabsahan anak yang itu mengandung dua unsur yang kontra-produktif, yaitu nilai kebaikan (mashlahah) dan keburukan (mafsadah).

a. Aspek Mashlahah / kebaikan

- Anak bisa memperoleh perlindungan hukum secara pasti.

- Anak memiliki hak menuntut tanggungjawab ayahnya bila lalai; dan antara keduanya bisa saling mewarisi.

- Anak merasa setara dengan teman-temannya dan tidak merasa hina karena memiliki ayah.

- Beban psikologis ibu dan anak menjadi tereliminir. Perasaan bangga mendapatkan keturunan (anak) yang sebenarnya hanya diperoleh sebagai akibat pernikahan yang sah bisa dinikmati oleh pasangan suami istri melalui kawin hamil.

- Menutup aib keluarga, Ibunya merasa tidak hina sebagai orang kotor dilingkungan masysrakat karena anak yang dilahirkannya memiliki ayah, yang sekaligus sebagai suaminya.

b. Aspek Mafsadah / keburukan

- Para remaja menjadi berpikiran pragmatis dalam pergaulan dengan lawan jenisnya. Pikiran tersebut mengarah kepada pergaulan bebas (free-sex). Dimana apabila terjadi kehamilan, nanti juga bisa melangsungkan perkawinan sehingga anaknya pun bisa menjadi anak sah dalam perkawinan tersebut.

- Anak luar nikah yang semula tidak dikehendaki keberadaannya secara geneologis, ia berasal dari 
orang tua yang tidak bisa mengendalikan nafsu sehingga berbuat dosa. Dengan kata lain gen yang menyebabkan sifat negatif dari orang tuanya akan menurun kepada anaknya. Seperti kata pepatah"Apa yang dimiliki seorang ayah juga dimiliki anaknya.

- Penilaian minor masyarakat yang dapat memicu tindakan brutal dan keonaran.

- Pengabsahan anak bisa merusak dan mengganggu keturunan keluarga dan kebersihannya.

Anak menurut hukum dibedakan menjadi dua, yaitu antara anak sah dan anak tidak sah. Menurut Pasal 250 KUHPerdata dan Pasal 42 UU Nomor 1 Tahun 1974 Tentang Perkawinan (selanjutnya disebut UUP) yang dimaksud dengan anak sah adalah anakanak yang dilahirkan sepanjang perkawinan, atau dengan kata lain dapat diartikan sebagai anak yang dilahirkan sebagai akibat perkawinan yang sah. ${ }^{4}$

Sedangkan anak tidak sah tidak dijelaskan secara eksplisit dalam PasalPasal KUHPerdata maupun UUP, tetapi secara a-contrario anak tidak sah dapat diartikan sebagai anak yang dilahirkan oleh seorang wanita yang tidak terikat dalam suatu perkawinan yang sah dengan seorang laki-laki.

Dari pembedaan kedudukan anak dalam hukum ini terdapat unsur yang sangat menentukan, yaitu perkawinan.

${ }^{4}$ J. Satrio I, Hukum Keluarga Tentang Kedudukan Anak Dalam Undang-undang, PT Citra Aditya Bakti, h. 5.

Anak tidak sah pada dasarnya adalah keturunan yang kelahirannya tidak didasarkan atas suatu perkawinan yang sah. Anak tidak sah dalam arti luas meliputi anak luar kawin, anak zina, dan anak sumbang. Sedangkan dalam arti sempit yang dimaksud dengan anak tidak sah terbatas pada anak luar kawin saja.

Masing-masing pembedaan anak tidak sah ini menurut KUHPerdata memiliki akibat yang berbeda.

a) Anak luar kawin, yang disebut juga anak tidak sah dalam arti sempit adalah anak yang dilahirkan dari hasil hubungan antara seorang laki-laki dan seorang perempuan yang kedua-duanya tidak terikat perkawinan dengan orang lain dan tidak ada larangan untuk saling menikahi;

b) Anak zina adalah anak yang dilahirkan dari hubungan luar nikah antara seorang laki-laki dan seorang perempuan, dimana salah satu atau kedua-duanya terikat perkawinan dengan orang lain;

c) Anak sumbang adalah anak yang dilahirkan dari hubungan antara seorang laki-laki dan seorang perempuan yang antara keduanya berdasarkan undang-undang (Pasal 31 KUHPerdata) ada larangan untuk saling menikahi.

Dilihat dari Hukum Islam, ada yang dinamakan dengan kawin hamil. Mengenai kawin hamil dijelaskan dalam

Pasal 53 Kompilasi Hukum Islam ("KHI"), yaitu seorang wanita hamil di luar nikah, dapat dikawinkan dengan pria yang menghamilinya. Perkawinan dengan wanita hamil tersebut dapat dilangsungkan tanpa menunggu lebih dahulu kelahiran anaknya. Dengan dilangsungkannya perkawinan pada saat wanita hamil, tidak diperlukan perkawinan ulang setelah anak yang dikandung lahir. Jika wanita tersebut telah menikah dengan pria yang menghamilinya sebelum anaknya 
dilahirkan, maka berdasarkan Pasal 99

KHI, anak tersebut adalah anak yang sah. Ini karena anak yang sah adalah:

a. Anak yang dilahirkan dalam atau akibat perkawinan yang sah

b. Hasil pembuahan suami istri yang sah di luar rahim dan dilahirkan oleh istri tersebut.

Berdasarkan pasal - 99 ayat a ini, jelas bahwa anak zina yang lahir setelah ibunya dinikahi penghamilnya seperti diatur dalam pasal 53 ayat $1 \mathrm{KHI}$ adalah anak sah. Sebabnya ialah anak tersebut dilahirkan dalam perkawinan yang sah. Anak ini bukan anak yang lahir di luar perkawinan. Anak yang lahir di luar perkawinan - menurut pasal $186 \mathrm{KHI}$ - hanya mempunyai hubungan saling mewaris dengan ibunya dan keluarga dari pihak ibunya. Oleh karena anak ini dilahirkan dalam perkawinan yang sah, maka ia saling mewaris tidak saja dengan ibu dan keluarga dari pihak ibunya, tetapi juga saling mewaris dengan bapak dan keluarga dari pihak bapaknya. Dengan kata lain, tidak ada perbedaan antara anak ini dan anak yang lahir akibat perkawinan yang sah.

Sekalipun merujuk pada kitabkitab fiqh, ternyata dalam hubungannya dengan status anak yang lahir dalam perkawinan, KHI tidak memberi batasan, sebagaimana fiqh. Seperti diketahui fiqh memberi tenggang waktu minimal 6 bulan antara kelahiran dan akad nikah menurut Abu Hanifah, atau antara kelahiran dan persetubuhan yang terjadi setelah akad nikah menurut Malik dan Syafi'i baru anak tersebut dapat dinasabkan kepada bapaknya. Jika kurang dari 6 bulan, tidak dapat dipertalikan nasab tersebut. Dengan demikian jika pasal 99 a KHI di atas diinterpretasikan dengan tolok ukur fiqh Malik dan al-Syafi'i, sekalipun anak tersebut lahir begitu akad nikah selesai, tetap tergolong anak sah sepanjang persetubuhannya terjadi minimal 6 bulan sebelum anak tersebut dilahirkan. Sedang jika tolok ukur fiqh Abi Hanifah yang digunakan, baru dipandang sah jika anak tersebut lahir minimal 6 bulan setelah terjadinya akad nikah. Oleh karena baik pasal 53 ayat 1 maupun pasal 99a KHI, bertujuan antara lain untuk melindungi anak dimaksud, maka tolok ukur fiqh Malik dan Al-Syafi'i lebih sejalan dengan tujuan tersebut.

Fiqh secara tegas menyatakan bahwa anak zina dapat saling mewarisi dengan ibu dan keluarga pihak ibu. Sedang dengan bapak dan keluarga pihak bapak tidak dapat saling mewarisi. Alasan yang dikemukakan fiqh, ialah adanya kejelasan hubungan nasab antara anak dengan ibunya melalui adanya indikasi bahwa ibu tersebutlah yang nyata-nyata mengandungnya. Oleh karena itu mereka saling mewarisi. Sedang antara anak dengan bapak, kejelasan hubungan nasab didasarkan atas adanya akad nikah dengan ibu anak tersebut, karena tidak ada indikasi selainnya yang dapat dijadikan pegangan. Demikianlah fiqh dahulu memberikan ketentuan.

KUHPerdata menganut asas bahwa seorang anak luar kawin baru memiliki hubungan perdata baik dengan ayah maupun ibunya setelah mendapat pengakuan, hal ini bias kita temukan dari makna yang terkandung dalam Pasal 280 KUH Perdata. Memang terasa agak aneh karena ada kemungkinan seorang anak secara yuridis tidak mempunyai ayah maupun ibu, ketika ayah maupun ibu tidak atau lalai melakukan pengakuan terhadap anak luar kawinnya. ${ }^{5}$

Kedudukan anak didalam KUH Perdata di bedakan menjadi:

1. Anak Sah

2. Anak luar kawin 
Pasal

250

KUH

Perdatamenyebutkan bahwa :

"Tiap-tiap anak yang dilahirkan atau tumbguh sepanjang perkawinan memperoleh si suami sebagai bapaknya"

Dari Pasal tersebut dapat ditarik kesimpulan bahwa anak sah menurut KUHPerdata adalah anak yang lahir atau anak yang ditimbuhkan dalam suatu perkawinan dan mendapat suami sebagai bapaknya dan pengertian sebaliknya dari rumusan pasal di atas dikategorikan sebagai anak tidak sah.

Anak-anak tidak sah yang termasuk dalam kategori anak zina dan anak sumbang merupakan anak luar kawin yang boleh untuk disahkan atau diakui oleh kedua orang tuanya. ${ }^{6}$

KUH Perdata menentukan bahwa jika suatu kelahiran anak kurang dari seratus delapan puluh hari (6 bulan), maka kelahiran tersebut dianggap tidak wajar dihitung dari saat melangsungkan perkawinan, maka pihak suami dapat mengajukan sangkalan bahwa anak yang lahir tersebut bukanlah anak yang dihasilkan dari benihnya, namun harus digais bawahi, bahwa hak suami untuk menyangkal anak yang lahir dari rahim istrinya itu bukanlah anaknya jika si suami sebelum melakukan perkawinan memang tidak pernah melakukan hubungan seks dengan istrinya sehingga dia menduga bahwa sebelum perkawinan istrinya telah hamil dengan laki-laki lain. $^{7}$

Namun secara spesifik bukan itu yang menjadi masalah bagi penulis, hal diatas hanyalah sebagai pengetahuan tentang hak penyangkalan anak oleh suami, yang menjadi masalah adalah pengaturan kedudukan hukum bagi anak yang lahir karena perkawinan dalam keadaan hamil (married by accident) di tinjau dari hukum perdata.

Sudah dijelaskan dalam pembahasan sebelumnya bahwa kedudukan anak di dalam KUH Perdata dibedakan menjadi dua yaitu Anak sah dan Anak luar kawin.

${ }^{5}$ D.Y Witanto. Hukum Keluarga Hak dan Kedudukan anak luar kawin. Prestasi Pustakaraya. Jakarta. 2012. h. 107

${ }^{6}$ D.Y Witanto. Op.cit. h. 110

7 Ibid.

Bila kita fahami bersama Anak yang lahir karena Perkawinan dalam keadaan hamil tersebut termasuk dalam kategori anak sah,hal ini dapat dijelaskan dalam Pasal $250 \mathrm{KUH}$ Perdata. Bahwa anak yang lahir karena Perkawinan dalam keadaan hamil itu termasuk Anak yang lahir sepanjang perkawinan juga merupakan anak yang ditumbuhkan sepanjang perkawinan.

Hukum kewarisan sering dikenal dengan istilah faraidh. Hal ini karena dalam Islam, bagian-bagian warisan yang menjadi hak ahli waris telah ditentukan dalam Al Qur'an. Hukum kewarisan dalam Islam mendapat perhatianbesar, karena pembagian warisan sering menimbulkan akibatakibat yang tidak menguntungkan. ${ }^{8}$

Secara etimologis, faraidh diambil dari kata fardh yang berarti taqdir "ketentuan". Dalam istilah syara' bahwa kata fardh adalah bagian yang telah ditentukan bagi ahli waris. ${ }^{9}$

Dalam bahasa Arab berpindahnya sesuatu dari seseorang kepada orang lain atau dari suatu kaum kepada kaum lain disebut Al-miirats. ${ }^{10}$ Sedangkan makna Al-miirats menurut istilah yang dikenal para ulama ialah berpindahnya hak kepemilikan dari orang yang meninggal kepada ahli warisnya yang masih hidup, baik yang ditinggalkan itu berupa harta (uang), tanah atau apa saja yang berupa hak milik legal menurut syari'i. Pengertian hukum kewarisan menurut Pasal 171 huruf a Kompilasi Hukum 
Islam adalah hukum yang mengatur tentang pemindahan hak pemilikan harta peninggalan (tirkah) pewaris, menentukan siapa-siapa yang berhak menjadi ahli waris dan berapa bagiannya masing-masing. Dalam konteks yang lebih umum, warisan dapat diartikan sebagai perpindahan hak kebendaan dari orang yang meninggal dunia kepada ahli warisnya yang masih hidup.

Mewaris berarti menggantikan tempat dari seseorang yang meninggal dalam hubungan hukum harta kekayannya. Hubungan-hubungan hukum yanglain, misalnya hubungan hukum dalam hukum keluarga.

\footnotetext{
8 Ahmad Rofiq , Hukum Islam di Indonesia, PT Raja GrafindoPersada, Jakarta, 1995, h.355.

9 Sayyid Sabiq,Fiqih Sunnah, Pena Pundi Aksara, Jakarta Selatan, 2006, h.479.

10 Muhammad Ali Ash-Shabuni, Pembagian Waris Menurut Islam, Gema Insani Press, Jakarta, 1995, h.33.
}

- Warisan itu menyalurkan pikiran dan perhatian orang ke arah suatu kejadian penting dalam suatu masyarakat tertentu, yaitu ada seorang anggota dari masyarakat itu meninggal dunia. ${ }^{12}$

Untuk itu, melihat hukum kewarisan Islam diperlukan wawasan kesejarahan, paling tidak sistem sosial dan sistem hukum yang melingkupi ketika Islam itu diturunkan. ${ }^{13}$

Hubungan anak dan orang tua menyangkut hak dan kewajiban masingmasing pihak. Dalam Al-Qur'an surah Al-Baqarah ayat 233, tentang kewajiban orang tua, disebutkan :

"Dan para ibu hendaklah menyusui anak-anaknya selama dua tahun penuh, bagi yang ingin menyempurnakan penyusuan. Dan kewajiban ayah memberi makan dan pakaian kepada para ibu dengan cara yang makruf. Seseorang tidak dibebani melainkan menurut kadar kesanggupannya. Janganlah seorang ibu menderita kesengsaraan karena anaknya dan juga seorang ayah karena anaknya, dan warispun berkewajiban demikian. Apabila keduanya ingin menyapih (sebelum dua tahun) dengan ....”.

Menurut ayat tersebut di atas, maka orang tua berkewajiban terhadap anaknya sesuai dengan kadar kemampuannya yaitu, memelihara, mengasuh, mendidik, menjaga dan melindunginya.

Menurut Abdur Rozak anak mempunyai hak-hak :

1. Hak anak sebelum dan sesudah dilahirkan.

2. Hak anak dalam kesucian keturunannya.

3. Hak anak dalam menerima pemberian nama yang baik.

4. Hak anak dalam menerima susuan.

5. Hak anak dalam mendapatkan asuhan, perawatan dan pemeliharaan.

6. Hak anak dalam kepemilikan harta benda atau hak warisan demi kelangsungan hidupnya.

7. Hak anak dalam bidang pendidikan dan pengajaran.

Hubungan yang kokoh dari hubungan pertalian darah oleh hukum syara' diberikan hak dan kewajiban antara orang tua dan anak. Adanya hubungan nasab antara orang tua dengan anak, menimbulkan hak-hak anak atas orang tuanya, yaitu:

11 Syamsul Rijal Hamid, Buku Pintar Agama Islam, Cahaya Salam, Bogor, 2011, h.366. 
12 Wirjono Prodjodikoro, Hukum Warisan di Indonesia,Sumur Bandung, Bandung, 1991, h.11.

${ }^{13}$ Ahmad Rofiq, Op.Cit., h.358

\section{1) Hak Radla'}

Hak Radla' artinya hak anak untuk mendapatkan pelayanan makanan pokoknya dengan jalan menyusu pada ibunya.

2) Hak Hadlanah

Menurut Bahasa kata

"hadlanah" berarti meletakkan sesuatu dekat tulang rusuk seperti menggendong, atau meletakkan sesuatu dalam pangkuan. Menurut istilah fikih, hadlanah ialah tugas menjaga dan mengasuh atau mendidik bayi atau anak kecil sejak ia lahir sampai mampu menjaga dan mengatur dirinya sendiri.

3) Hak Walayah (Perwalian)

Dalam pemeliharaan anak dari kecil sampai baligh selain ada hak hadlanah juga terdapat hak perwalian. Tugas perwalian selain mengandung pengertian dalam pernikahan, juga untuk tugas pemeliharaan atas diri anak semenjak berakhir periode hadlanah sampai ia berakal, atau sampai menikah bagi anak perempuan dan perwalian dalam hal harta.

Dalam Hukum Islam, perwalian anak dibagi menjadi tiga, yaitu :

- Perwalian dalam pemeliharaan dan pendidikan anak

- Perwalian harta

- Perwalian nikah

4) Hak Nafkah

Hak untuk mendapatkan nafkah adalah hak anak yang berhubungan langsung dengan nasab.Begitu anak lahir, maka hak nafkahnya sudah mulai harus dipenuhi.Hak nafkah anak ini saling terkait dengan masing-masing hak-hak di atas.
Menurut para ahli fikih, orang yang pertama yang bertanggung jawab atas nafkah anak adalah kerabat terdekat dalam garis nasab, dan dalam hal ini adalah ayah kandung.

Implikasi hukum bagi anak sah meliputi hubungan nasab, mahram dan hak waris. Sedangkan dalam fenomena pengabsahan anak, semua ulama meniadakan hubungan nasab dan menolak pemberian hak waris bagi anak zina yang disahkan. Sebab anak itu bukan anak sah secara syar'i. Sedangkan dalam hubungan kemahramannya itu para ulama berbeda pendapat . Karena secara genealogis, anak itu haram dinikahi oleh ayahnya. Sedangkan anak zina tersebut hanya mempunyai hubungan nasab maupun perdata dengan ibunya dan keluarga ibunya

Adapun anak dari hasil hubungan zina, maka setelah perkawinan kedua orang tuanya dapat ditetapkan dengan dua kemungkinan, yakni:

a) Bila anak tersebut lahir 6 (enam) bulan lebih setelah perkawinan sah kedua orang tuanya, maka nasab nya adalah kepada Suami yang telah mengawini ibunya itu.

b) Bila anak tersebut lahir kurang 6 (enam) bulan setelah perkawinan sah kedua orang tuanya, maka nasab anak tersebut adalah kepada ibunya.

Hal ini bersesuaian dengan pendapat jumhur ulama' diantaranya Syekh Muhammad ZaidAlAbyani yang menyatakan bahwa batas minimal umur kandungan adalah 180 hari $=6$ bulan. Para Ulama' mendasarkan hukumnya dari perpaduan dua ayat, masing masing dari Surat AlAhqoof 15 dan Surat Luqman ayat 14.

Menurut Surat Al- Ahqoof 15, waktu mengandung dan menyapih $=30$ bulan. 
Menurut Surat Luqman 14, waktu menyapih itu $=\underline{24 \text { bulan }(2 \text { tahun })}$

Jadi waktu hamil minimal $=6$ bulan

Sesuai dengan pernyataan tersebut, Imam Abu Hanifah menghitung jumlah 180 hari itu dari pernikahan, bukan dari mulainya hubungan sekssual diantara kedua orang tua biologisnya.

Maka jika si anak lahir kurang dari 6 bulan, bila si anak terlahir perempuan, jika ia nanti setelah dewasa hendak menikah, maka walinya bukan suami ibunya namun Wali Hakim. Tentu saja anak tersebut secara syar'i tidak mendapatkan hak waris sebagai anak yang sah dari suami ibunya itu bila nanti suami ibunya meninggal dunia dan meninggalkan harta warisan, terkecuali bila yang meninggal itu sebelumnya telah Iqror (membuat pernyataan) bahwa anak tersebut diakui sebagai anaknya sebagaimana diterangkan oleh Badran Abu Al-Ainain sebagai konsekwensi kebalikan pada kasus anak Li' an (suami yang menuduh istrinya mengandung bukan dari dirinya)

Hukum positif di Indonesia membedakan antara keturunan yang sah dan keturunan yang tidak sah. Keturunan yang sah didasarkan atas adanya perkawinan yang sah, dalam arti, bahwa yang satu adalah keturunan yang lain berdasarkan kelahiran dalam atau sebagai akibat perkawinan yang sah, anak-anak yang demikian disebut anak $\mathrm{sah}^{.14}$

Sedangkan keturunan yang tidak sah adalah keturunan yang tidak didasarkan atas suatu perkawinan yang sah, orang menyebut anak yang demikian ini adalah anak luar kawin.

${ }^{14}$ J. Satrio, Loc Cit

Anak yang dilahirkan diluar perkawinan yang sah adalah bukan anak yang sah, sehingga membawa konsekuensi dalam bidang perwarisan. Sebab anak yang dilahirkan di luar perkawinan hanya mempunyai hubungan perdata dengan ibunya dan keluarga ibunya (Pasal 43). ${ }^{15}$

Hubungan

kekeluargaan sedarah/nasab dalam Hukum Perdata mempunyai arti yang sangat penting.

Dengan adanya perbedaan status anak tersebut dalam Kitab Undangundang Hukum Perdata, menyebabkan timbulnya beberapa perbedaan dalam masalah mengenai:

- Hak memakai nama keluarga

- Pemberian izin perkawinan

- Hak untuk mewarisi

- Kekuasaan orang tua

Dari ketentuan di atas, maka menulis berpendapat bahwa anak yang dilahirkan dari perkawinan wanita hamil adalah memiliki hubungan nasab dengan kedua orang tuanya dan kedua orang tua anak tersebut wajib memenuhi kebutuhan anaknya, baik mendidik, memelihara, perwalian nikah dan mewakili dalam segala perbuatan hukum di dalam ataupun di luar Pengadilan serta segala hak-hak anak dari kedua orang tuanya dengan sendirinya melekat kepadanya, seperti hak nasab, hak warismewarisi, hak nafkah hak perwalian dan lain sebagainya.

Sebagaimana yang telah disebutkan pada awal tulisan ini, bahwa perkawinan wanita hamil akan membawa akibat hukum yang sama dengan perkawinan padaumumnya. Perkawinan yang dilakukan oleh wanita hamil dengan kawan zinanyaakan berakibat dihalalkannya para pihak berhubungan kelamin setelah akad nikahdilakukan tanpa menunggu kelahiran sang anak. Akibat hukum lain yang timbuladalah adanya hak dan kewajiban secara timbal balik antara suami kepada istri danjuga timbulnya 
hak-kak dan kewajiban antara orangtua kepada anak.

Dalam hal pelaksanaan kawin hamil akibat zina, dalam UU Perkawinan tidak mengatur secara jelas hal tersebut. UU Perkawinan hanya memberikan batasan asalkan perkawinan tersebut dilakukan atas dasar saling mencintai dan bertujuanmulia yaitu membentuk keluarga yang bahagia dan kekal yang didasarkan dandilakukan

${ }^{15}$ Riduan Syahrani, Seluk Beluk dan Asas-Asas Hukum Perdata.Penerbit Alumni Bandung. 1989. Cet II. h. 100-101.

menurut ketentuan hukum agama dan kepercayaannya masing-masing,maka tidak akan menjadi masalah apabila pada saat pernikahan terjadi, si wanitayang akan menikah dalam keadaan mengandung.

Pelaksanaan perkawinan yang didahului karena kehamilan yang diakibatkan pererzinaan akan membawa akibat hukum berupa hak dan kewajiban yang timbul diantara keduanya.

Jadi dapat ditarik kesimpulan bahwa Kompilasi Hukum Islam mengatur hak- hak dan kewajiban yang timbul diantara suami istri termasuk juga untuk suami istri yang perkawinannya diakibatkan oleh kehamilan diluar nikah (kawin hamil). Pandangan hukum Islam tentang akad nikah wanita hamil akibat zina adalah sah selama yang mengawini wanita hamil tersebut adalah laki-laki yang menghamilinya.Hal ini sesuai dengan Pasal 53 Kompilasi Hukum Islam yang merupakan Fiqih Islam yang diadopsi dan berlaku di Indonesia. KHI menyatakan bahwa seorang wanita yang hamil diluar nikah dapat dikawinkan dengan pria yang menghamilinya tanpa harus menunggu kelahiran sang anak terlebih dahulu dan tidak diperlukan perkawinan ulang setelah anak yang dikandungnya lahir.

Sedangkan konsep anak sah itu tidak hanya terbatas bagi anak yang lahir dari perkawinan yang sah, tetapi juga sebagai akibat dari perkawinan yang sah.Tetapi Hukum Islam memberikan batasan bahwa untuk menentukan anak tersebut dapat dinasabkan dengan ayahnya atau tidak tetap harus memperhitungkan lamanya janin dalam kandungan dihitung sejak perkawinan kedua orangtuanya.Jadi, apabila anak tersebut lahir setelah 6 bulan atau lebih setelah perkawinan kedua orangtuanya maka anak tersebut dapat dinasabkan dengan ayahnya.Tetapi jika anak tersebut lahir sebelum genap 6 bulan perkawinan orang tuanya, maka anak tersebut tidak dapat dinasabkan dengan ayahnya.

\section{KESIMPULAN}

Hak anak yang dilahirkan dari perkawinan wanita hamil menurut hukum Islam apabila anak tersebut dilahirkan lebih dari enam bulan masa kehamilan dari perkawinan sah ibunya atau dimungkinkan adanya hubungan badan, maka anak tersebut adalah anak sah sehingga memiliki hak terhadap kedua orang tuanya, yaitu hak radla', hak hadlanah, hak walayah (Perwalian), hak nasab, hak waris dan hak nafkah.

Status hukum anak hasil dari perkawinan.wanita hamil dalam hukum Islam adalah apabila anak tersebut lahir dari wanita hamil yang kandungannya minimal berusia 6 (enam) bulan dari perkawinan yang sah atau kemungkinan terjadinya hubungan badan antara suami isteri dari perkawinan yang sah tersebut maka anak itu adalah anak yang sah. Dan apabila anak tersebut dilahirkan kurang dari enam bulan masa kehamilan dari perkawinan sah ibunya atau 
dimungkinkan adanya hubungan badan maka anak tersebut dalam hukum Islam adalah anak tidak sah sehingga anak hanya berhak terhadap ibunya. Sedangkan dalam hukum positif di Indonesia status hukum anak hasil dari perkawinan wanita hamil adalah anak yang sah karena baik Kitab Undangundang Hukum Perdata, Undang-undang No. 1 Tahun 1974 tentang Perkawinanan dan Kompilasi Hukum Islam mengatur bahwa anak yang sah adalah anak yang dilahirkan akibat atau dalam perkawinan yang sah. Sehingga menurut hukum positif di Indonesia bahwa anak yang lahir dari perkawinan wanita hamil adalah anak sah dari kedua orang tuanya, sehingga ia memiliki hak-hak yang wajib dipenuhi oleh kedua orang tuanya yaitu kedua orang tua wajib memelihara dan mendidik anak-anak mereka sebaik-baiknya, orang tua mewakili anak tersebut mengenai segala perbuatan hukum di dalam dan di luar pengadilan, sebagai wali dalam perkawinan, hak nasab dan hak kewarisan.

\section{DAFTAR PUSTAKA}

Subekti, Pokok-Pokok Hukum Perdata, PT Intermasa.Jakarta. Cetakan ke XXXIII. Tahun 2002.

Johny Ibrahim, Teori \& Metode Penelitiah Hukum Normatif, Banyumedia Publiching Malang 2006

Mohammad Thalib. (Trans) Sayyid Sabiq, Fikih Sunnah. (Bandung : PT. Alma'arif, 1980. Jilid 6, Cet 15

J. Satrio I, Hukum Keluarga Tentang Kedudukan Anak Dalam Undangundang, PT Citra Aditya Bakti.

D.Y Witanto. Hukum Keluarga Hak dan Kedudukan anak luar kawin. Prestasi Pustakaraya. Jakarta. 2012.

Ahmad Rofiq, Hukum Islam di Indonesia, PT Raja GrafindoPersada, Jakarta,1995.

Sayyid Sabiq,Fiqih Sunnah, Pena Pundi Aksara, Jakarta Selatan, 2006.

Muhammad Ali Ash-Shabuni, Pembagian Waris Menurut Islam, Gema Insani Press, Jakarta, 1995.

Syamsul Rijal Hamid, Buku Pintar Agama Islam, Cahaya Salam, Bogor, 2011.

Wirjono Prodjodikoro, Hukum Warisan di Indonesia,Sumur Bandung, Bandung, 1991.

Ahmad Rofiq, Hukum Islam di Indonesia, PT Raja GrafindoPersada, Jakarta.

Riduan Syahrani, Seluk Beluk dan Asas-Asas Hukum Perdata.Penerbit Alumni Bandung. 1989. Cet II. 